DOI https://doi.org/10.18551/rjoas.2017-09.41

\title{
DISTRIBUTION, DENSITY AND IDENTIFICATION OF GIANT CLAMS IN COASTAL AREA OF NEGERI MORELLA, THE DISTRICT OF LEIHITU, CENTRAL MALUKU REGENCY, INDONESIA
}

\author{
Widyasari Ferliana, Arafat Gulam, Robiandi, Setiadi Didik, Rahmat Syahid, \\ Latulanit M. Nasrul, Fahlevi Arif Reza, Arisandy Kiki Riski \\ The Division of Coastal and Marine Resources Management, Sorong, Indonesia
}

\author{
Sayuti Mohammad* \\ Polytechnic of Marine and Fisheries, Sorong, Indonesia
}

*E-mail: mohsayut@gmail.com

\begin{abstract}
Giant clams are protected biota both nationally and internationally. The coastal area of Negeri Morella, the District of Leihitu, Central Maluku Regency, Maluku is one of the areas as the habitat of these giant clams. This study aims to identify the types of clams, conduct ecological studies covering density, diversity index of Tridacninae shells in Central Maluku, especially in Negeri Morella. Implementation of the clam population survey is conducted by using UVC (Underwater Visual Census). The results show that ofthe ten (10) samples in the observation station, 91 individuals of giant clams under the type of Tridacna squamosa and Tridacna crocea. The giant clams found in the coastal waters of Negeri Morella has a small size; in the depth of 1-5 m, 87 giant clams were found in various sizes with a length of 2-30 $\mathrm{cm}$, and in the depth of $5-10 \mathrm{~m}$, only four (4) giant clams with a length of $11-30 \mathrm{~cm}$. The population density obtained was 45.5 individuals/ha, the value of Diversity Index $\left(\mathrm{H}^{\prime}\right)$ was 0.69 , the Uniformity Index (E) ranged from 0-1, and the Dominance Index (D) of 0.505.
\end{abstract}

\section{KEY WORDS}

Density, Diversity Index, Giant Clams, Morella, Tridacna, UVC

Giant clams (Bivalvia, Cardiidae) are marine mollusks that live in coral reefs in the Indo-Pacific region. They come in two genera (Tridacna and Hippopus) with nine species, seven species of which are found in Indonesia. Geographically, these shells have limited distribution in the tropical region of Indo-Pacific, from the Red Sea to the Pacific Islands of Tuamotu (Yusuf et al., 2009). Tridacninae shells live in shallow waters, at a depth of 1 to 20 m (Hernawan, 2011). Tridacninae shells ecologically are biota which act as a natural bio filter, as they are able to filter ammonia and nitrate dissolved in seawater for the need of zooxanthellae of nitrogen for growth process (Braley, 1985). Tridacninae is known to have an important economic value because apart from being a source of food, the shells can be used as decoration materials and jewels. In addition, the shells are so much sought for jewelry and for the industry of terrazzo tiles, leading to the decreasing population of the species (Nontji, 2002).

Giant clams are protected biota both nationally and internationally. Internationally all types of clams included in the II CITES Appendix since 1985. Nationally, the giant clams are protected under Government Regulation Number 7 of 1999 that includes seven types of clams living in the waters of Indonesia. Their status are protected animals, where all forms of exploitative utilization (poaching and trade) are not permitted, excluding the results of cultivation, and after being given the status for game hunting (in accordance with Government Regulation Number 8 of 1999).

One of the coastal areas in Indonesia as the home of giant clams is the coastal area of Negeri Morella, the District of Leihitu, Central Maluku Regency, Maluku. The majority of the people here are farmers and fishermen. Along the coastal area are the home of giant clams, and the place of recreation and fish capture. 


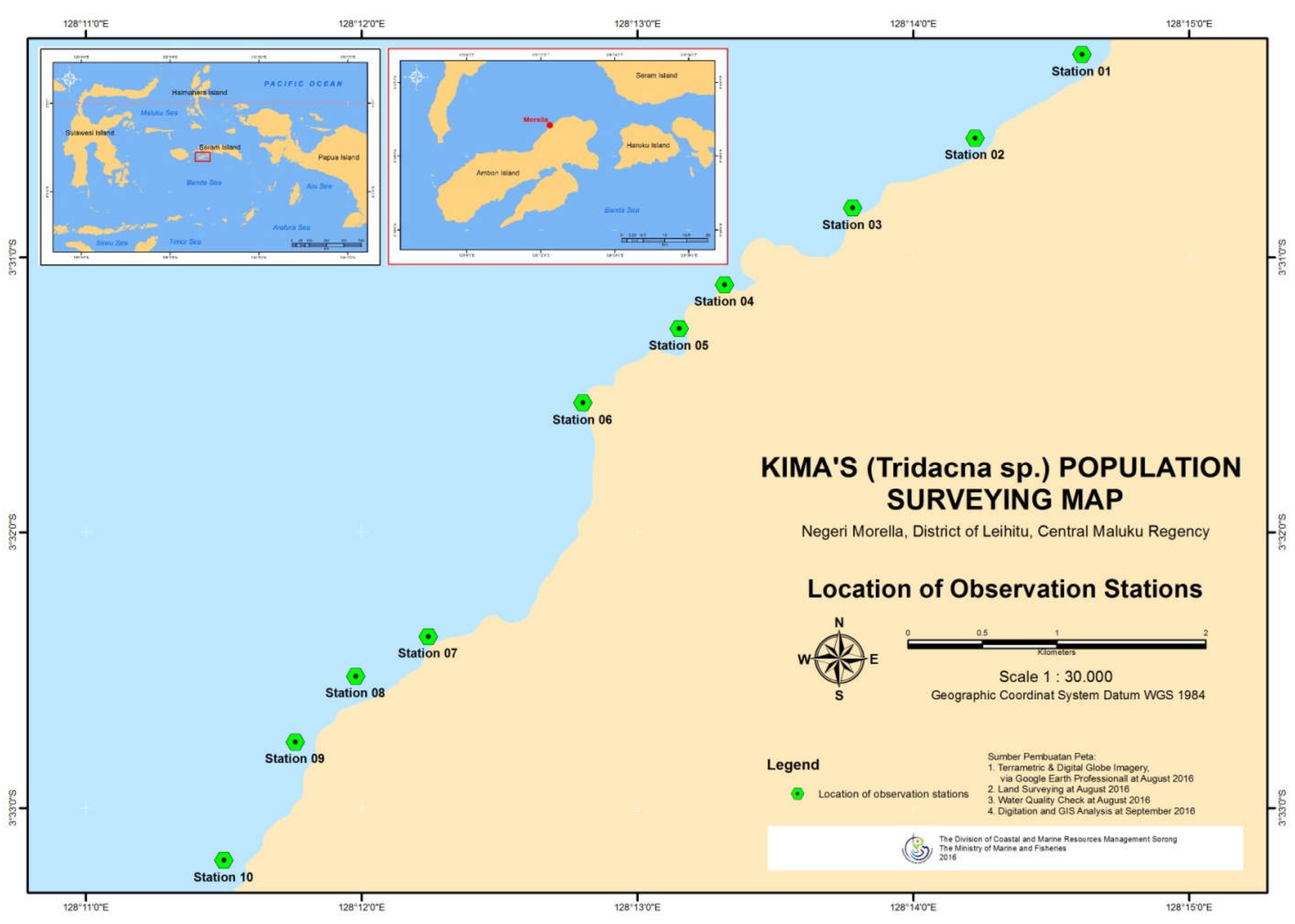

Figure 1 - Survey Sites (Observation Stations) 
The giant clams here are used as a food source traditionally. The local people call the giant clams as "biagaru". The use of the giant clams as a food source and jewelry has been done for generations. This also has caused the population of the giant clams to decrease.

Scientific information for types of Tridacninae in the region of Central Maluku, especially in the waters of Negeri Morella is not available; therefore the research aims to identify the types of clams through an ecological study which includes examination on the density and diversity index of Tridacninae.

\section{MATERIALS AND METHODS}

Population Survey Method. Clam population survey is conducted using UVC (Underwater Visual Census). There are two teams, each of two (2) people plus one (1) boat driver. These monitoring resources at least have an A1 diving license or equivalent and have good understanding of UVC method and types of clams. The boat drivers are fishermen of good knowledge about the locations potential for clams in the territorial waters of Negeri Morella and have the ability to use GPS (Global Positioning System). To estimate the population of giant clams, sampling is ten (10) observation stations representing the entire territory of the coastal area of Negeri Morella with a coastline of $\pm 10.7 \mathrm{~km}$. Each station represents a one-kilometer coastline, with a hundred-meter transect at two depths. If the reef is steep in the stations, two repetitions with the same depth are done.

The procedure for giant clam survey is as follows:

1. Determine the location and number of monitoring stations starting from the shoreline as the 0 point. Mount the peg as a marker and record the coordinates;

2. Expand the rope starting from the point $0,100 \mathrm{~m}$ parallel to the shoreline to a depth of 3-15 m;

3. Write down all the individuals and types of clams found under the transect line and as far as $5 \mathrm{~m}$ of the observation area for each observer so that the total range of both observers is $10 \mathrm{~m}$. The total area of observation is $10 \mathrm{~m} \times 100 \mathrm{~m}$ or $1,000 \mathrm{~m}^{2}$;

4. Record all types of clam found in the observation area. Measure the shell width using stainless ruler. All data is recorded into the observation sheet (slate or waterproof paper) for further processing;

5. Record other information such as coastal vegetation, the slope of the reef, conditions (sand and rubble), and if possible record the former bomb and coral bleaching due to rising sea surface temperatures or predation by Achantasterplancii.

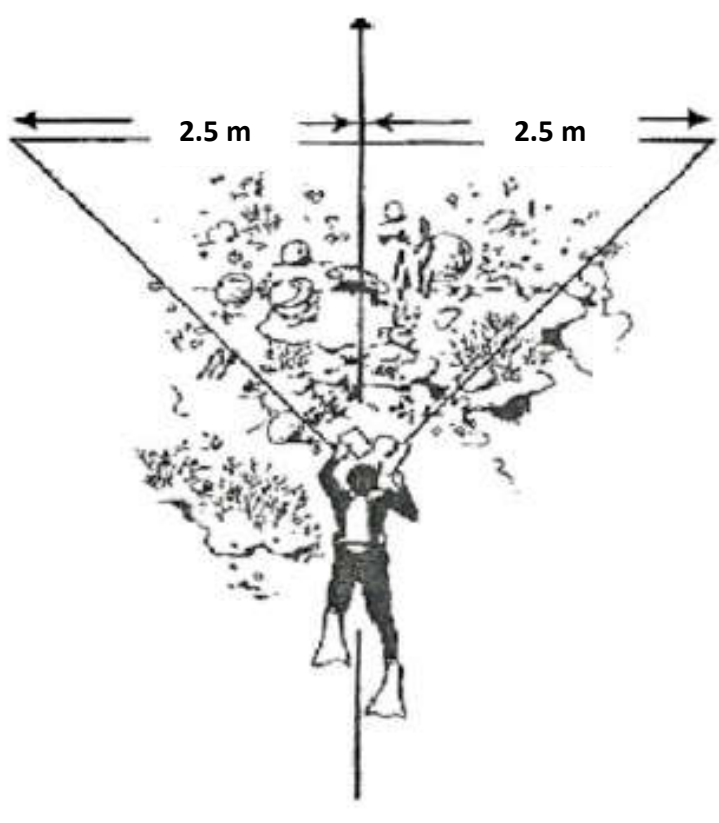

(a)

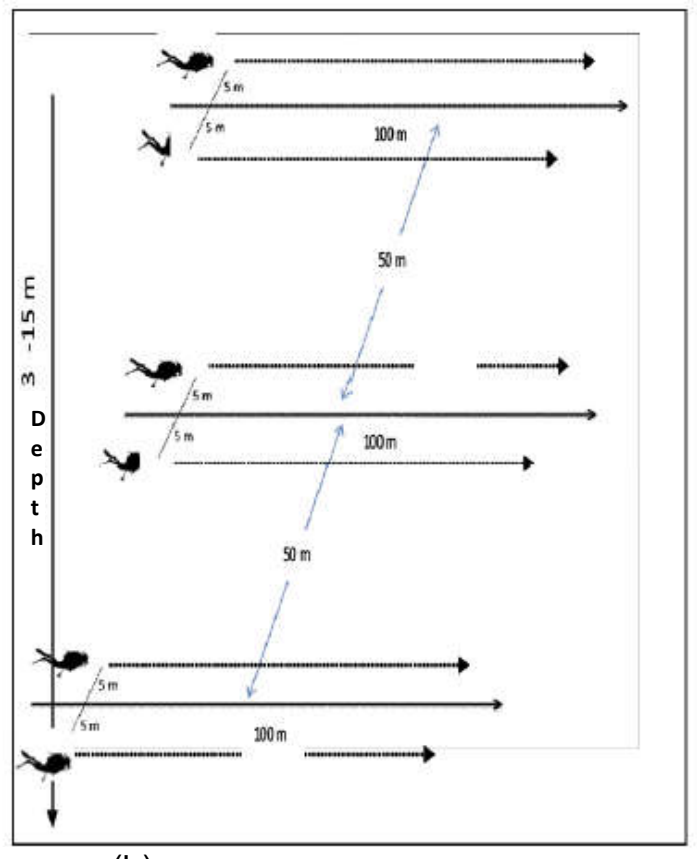

(b)

Figure 1 - (a) Range of observation of an observer; (b) UVC Method 
Calculating the Density and Diversity Index of the Giant Clams:

Density. Density refers to the number of individuals per unit area of each station.

$$
\mathrm{X}=\frac{\Sigma \mathrm{x}}{\mathrm{n}}
$$

Where: $X=$ the average number of clams per unit area; $\Sigma x=$ number of clams in unit number $\mathrm{I} ; \mathrm{N}=$ the width of unit number $\mathrm{i}$.

Diversity Index. Diversity index refers to a structure of organism communities to ease analysis on information about the type and number of species. The more types of biota in waters, the higher diversity of the waters is. Diversity index calculation is done using the Shannon-Wiener formula (Magurran, 2004) as follows:

$$
\mathrm{H}^{\prime}=-\left(\sum \frac{n t}{N} \ln \frac{n t}{N}\right)
$$

Where: $H^{\prime}=$ diversity index; $n_{1}=$ number of each individual of each type; $n=$ total number of all individuals of all types.

Based on the formula of diversity index, the diversity is categorized as follows:

$$
\begin{gathered}
H^{\prime}<1=\text { low diversity } \\
1<H^{\prime}<3=\text { medium diversity } \\
H^{\prime}>3=\text { high diversity }
\end{gathered}
$$

Evenness Index. Evenness expresses how evenly the individuals in a community are distributed among the different species (Odum, 1971). Index is obtained by comparing the diversity index to the maximum value as follows:

$$
\mathrm{E}=\frac{\mathrm{H}^{\prime}}{\mathrm{H}^{\prime} \text { maks }}
$$

Where: $E=$ evenness index; H'max $=\ln \mathrm{s} ; \mathrm{S}=$ the number of biota.

The value ranges between 0 to 1 . The smaller the value of $E$, the less even the biota is. This shows that the distribution of each type is different and there is a possibility that a type of biota dominates the population. In contrast, the bigger the value of $\mathrm{E}$, then the higher the evenness of the biota is. This shows that the number of individual of each type is the same, in which a type of biota does not dominate the population.

Dominance Index. Using the dominance index by Simpson (Krebs, 1989) as follows:

$$
D=\sum_{i=1}^{\infty}\left[\frac{N i}{N}\right]^{2}
$$

Where: $\mathrm{D}=$ Simpson dominance index; $\mathrm{Ni}=$ the number of individual number $\mathrm{I} ; \mathrm{N}=$ the total number of individuals; $S=$ the type number.

The domination index is classified as follows:

$$
\begin{gathered}
0<D \leq 0.05 \text { low dominance } \\
0.5<D \leq 0.75 \text { medium dominance } \\
0.75<D \leq 1.00 \text { high dominance }
\end{gathered}
$$

\section{RESULTS AND DISCUSSION}

Population of Giant Clams. To know the population of giant clams in the waters of Negeri Morella, sampling has been done in ten (10) observation stations representing all the waters in Morella with a coastline of \pm 10.7 kilometers with a coordinate of observation station 1 at $128^{0} 14^{\prime} 38.40^{\prime \prime} \mathrm{EL}, 3^{0} 30^{\prime} 15.80^{\prime \prime} \mathrm{SL}$; station 2 at $128^{\circ} 14^{\prime} 13.20^{\prime \prime} \mathrm{EL}, 3^{0} 30^{\prime} 34.02^{\prime \prime} \mathrm{SL}$; station 
3 at $128^{0} 13^{\prime} 48.00^{\prime \prime} \mathrm{EL}, 3^{0} 30^{\prime} 49.25^{\prime \prime} \mathrm{SL}$; station 4 at $128^{0} 13^{\prime} 19.20^{\prime \prime} \mathrm{EL}, 3^{0} 31^{\prime} 5.99^{\prime \prime} \mathrm{SL}$; station 5 at $128^{0} 13^{\prime} 8.40^{\prime \prime} \mathrm{EL}, 3^{0} 31^{\prime} 15.60^{\prime \prime} \mathrm{SL}$; station 6 at $128^{0} 12^{\prime} 46.80^{\prime \prime} \mathrm{EL}, 3^{0} 31^{\prime} 31.76^{\prime \prime} \mathrm{SL}$; station 7 at $128^{0} 12^{\prime} 14.40^{\prime \prime} \mathrm{EL}, 3^{0} 32^{\prime} 22.74^{\prime \prime} \mathrm{SL}$; station 8 at $128^{\circ} 12^{\prime} 00.00^{\prime \prime} \mathrm{EL}, 3^{0} 32^{\prime} 31.38^{\prime \prime} \mathrm{SL}$; station 9 at $128^{\circ} 11^{\prime} 45.60^{\prime \prime} \mathrm{EL}, 3^{0} 32^{\prime} 45.67^{\prime \prime} \mathrm{SL}$; and station 10 at $128^{0} 11^{\prime} 31.20^{\prime \prime}$ ELdan $3^{0} 33^{\prime} 11.45^{\prime \prime} \mathrm{SL}$. The population of giant clams is presented in Table 1.

Table 1 - Number and Type of Giant Clam Population in Morella

\begin{tabular}{|c|c|c|c|c|c|c|c|c|c|c|c|}
\hline \multirow{2}{*}{ Type of Giant Clam } & \multicolumn{10}{|c|}{ The Number of Giant Clam Population at Station } & \multirow{2}{*}{ Total } \\
\hline & $\mathrm{I}$ & II & III & IV & $\mathrm{V}$ & $\mathrm{VI}$ & VII & VIII & IX & $\mathrm{X}$ & \\
\hline Tridacna squamosa & 8 & 8 & 1 & 1 & 2 & 10 & 8 & 8 & 0 & 4 & 50 \\
\hline Tridacna crocea & 0 & 1 & 0 & 0 & 1 & 12 & 15 & 6 & 5 & 1 & 41 \\
\hline Amount & 8 & 9 & 1 & 1 & 3 & 22 & 23 & 14 & 5 & 5 & 91 \\
\hline
\end{tabular}

During observation, 91 giant clams were found. The highest number was in station 7 , as many as 23 giant clams, followed by station 6 , as many as 22 clams, and the lowest was in station 3 and 4 , as many as 1 clam.

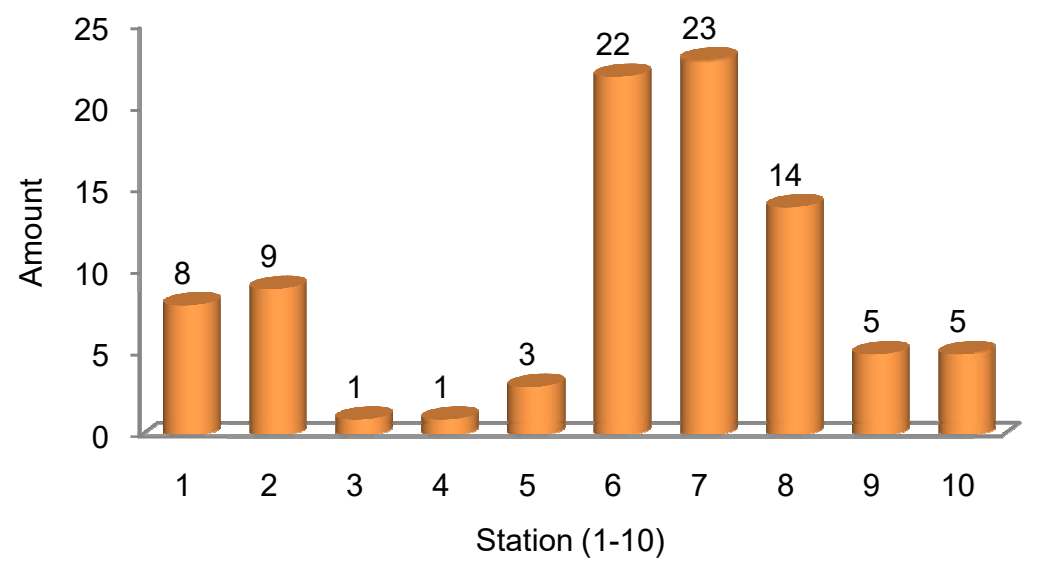

Figure 3 - The number of giant clams per station

During the observation using visual census, two types of clams i.e. Tridacna squamosa, as many as 50 individuals, and Tridacna crocea, as many as 41 individuals, were found. The percentage of the two types of giant clams can be seen in the image below:

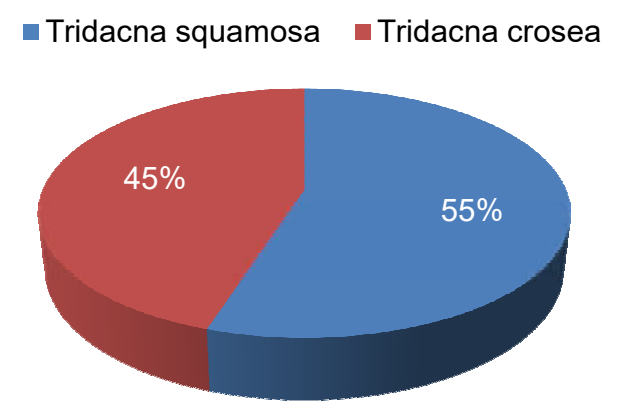

Figure 4 - Percentage of Giant Clams

The giant clams Tridacna squamosa $L$ have a symmetrical shell and wavy shell opening. The upper valvehas flattish folds that interlock at the margin with similar folds on the lower valve so that they can clamp together and the shell can close tightly. The mantle usually brownish color, and may be various mixtures of black and white, as well as orange, yellow, or often with brilliant blue or green lines depending on the symbiotic algae. Tridacna squamosa found during the survey have a size range of $4-30 \mathrm{~cm}$, and this is consistent with 
the statement that the clamshell is able to grow to the size of $40 \mathrm{~cm}$ length. The people in Morella utilize these clams as a food source and they take the clams during the low tide (Wells, 1997).

The giant clams Tridacna crocea begin to cling on the substrate surface in the form of hard rock while still a juvenile form with a size of 4-20 mm (Kawaguti, 1983; Suzuki, 1998). A piece of mantle tissue that comes out of the openings in the byssus at the bottom shell serves as a permanent adhesive. The mantle tissue at the base of the shell also produces a weak acid that can soften or dissolve limestone $(\mathrm{CaCO} 3)$ that over time hard coral surface begins to form a hole. After a hole is formed, the giant clams continue to issue a weak acid to soften the lime around the shell (Hedley, 1921). The mechanical movement to open and close the shell will erode the already fragile coral part that the hole grows even larger (Yonge, 1936; Hamner and Jones, 1976). The size of Tridacna crocea found during the survey was in a range of $2-10 \mathrm{~cm}$. Tridacna crocea has the slowest growth rate in comparison with other types of clams. Shell size increases only 1-2 mm per month.

Population based of the Number and Size of Clamps. The giant clams found during observations consisted of a variety of lengths, the largest size with a length of $30 \mathrm{~cm}$, and the smallest size with a length of $2 \mathrm{~cm}$. The average size mostly found was with the length below or equal to $10 \mathrm{~cm}$, as many as 70 individuals. Clam population based on the number and size of clams is presented in the following figure.

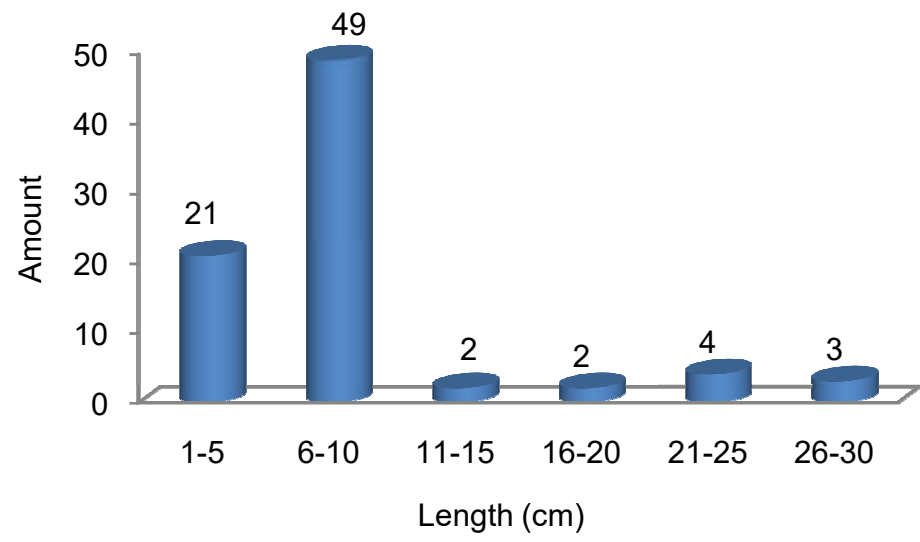

Figure 5 - The Length of the Giant Clams Found

The giant clams found in the territorial waters of Negeri Morella have a small size. In the depth of $1-5 \mathrm{~m}$, clams were found in various sizes with a length of $2-30 \mathrm{~cm}$ by 87 individuals, and in the depth of 5-10 m, clams found were only four (4) with a length of 11-30 $\mathrm{cm}$.

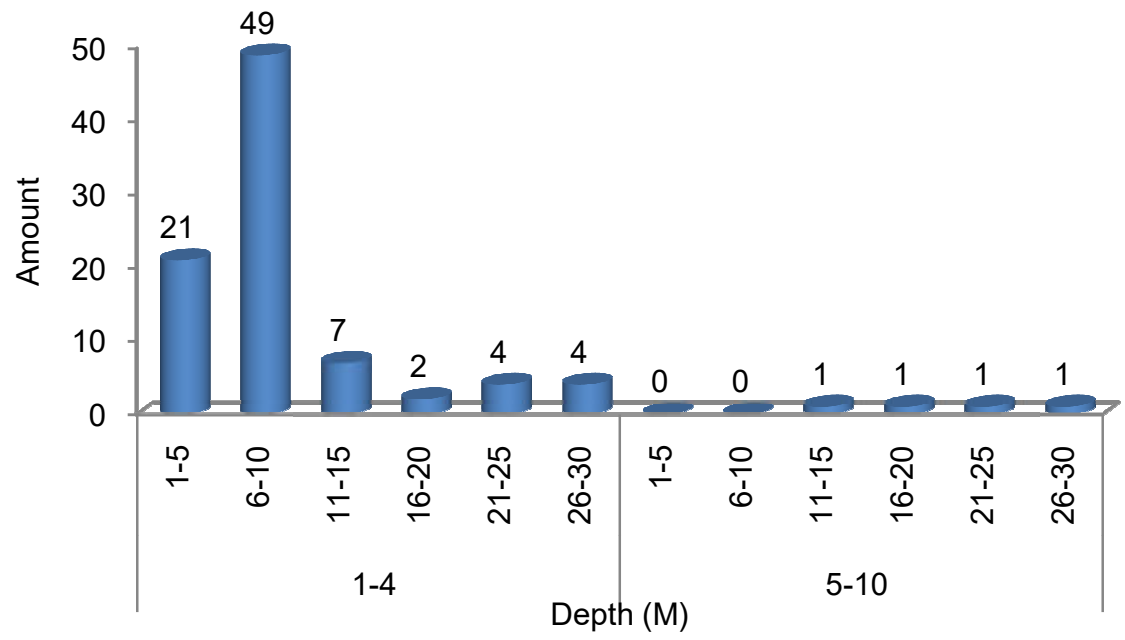

Figure 6 - Distribution of the Giant Clams' Length based on Depth 
Distribution of the Giant Clams' Length based on Depth. The small-sized clams were mostly found in shallow waters, while the large-sized clams were found in a depth of more than $5 \mathrm{~m}$.

Distribution of the Giant Clams' Number based on Depth. In the depth of 1-4 $\mathrm{m}$, there were 89 clams found in 10 stations with a percentage of $97.8 \%$, while in the depth of $5-10 \mathrm{~m}$, there were four (4) clams found in 3 stations with a percentage of $4.39 \%$.

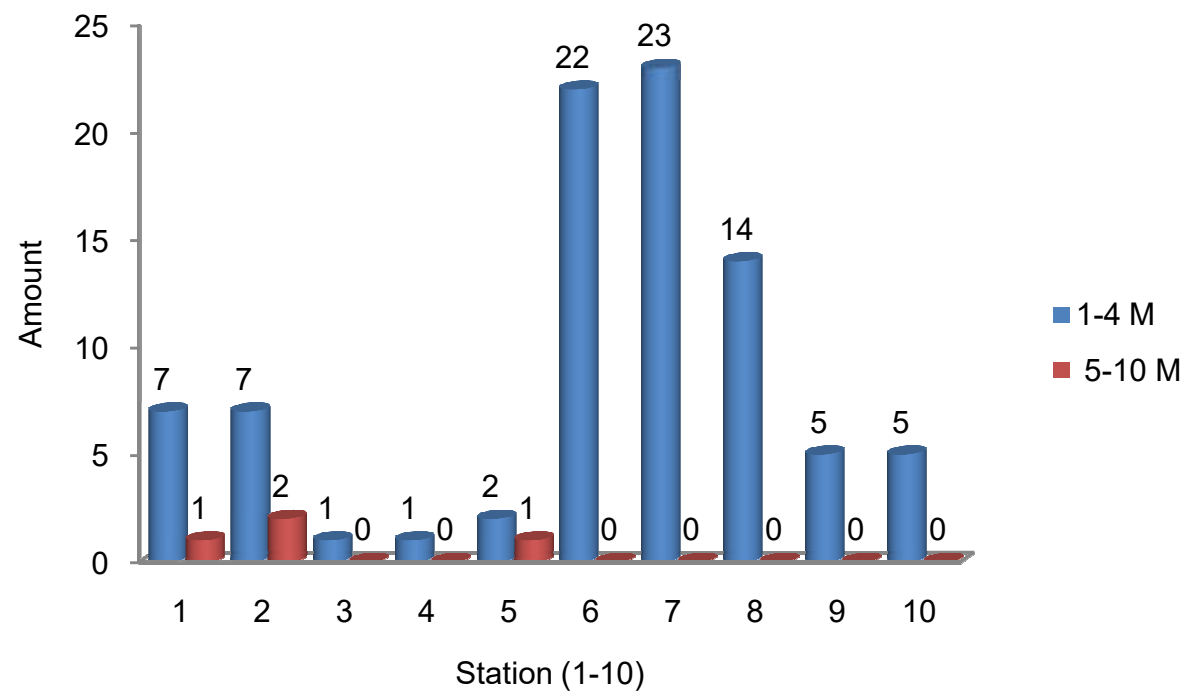

Figure 7 - The Number of the Giant Clams Found based on Depth

Density, Diversity Index, Evenness, and Dominance. The results of calculation on the density of clams in Negeri Morella produces a value of 0.0045 individuals $/ \mathrm{m}^{2}$ or 45.5 individuals/ha. The highest individual density of Tridacna squamosa $L$ is 0.0025 individuals $/ \mathrm{m}^{2}$ or 25 individuals/ha, while the density of Tridacna crocea is 0.002 Individual $/ \mathrm{m}^{2}$ or 20.5 individuals/ha.

Table 2 - Density, Diversity Index, Evenness, and Dominance

\begin{tabular}{cccccccc}
\hline No & Type & Number & $\mathrm{X}(\mathrm{ha})$ & $\mathrm{X}\left(\mathrm{m}^{2}\right)$ & $\mathrm{H}^{\prime}$ & $\mathrm{E}$ & $\mathrm{D}$ \\
\hline 1 & Tridacna squamosa & 50 & & & 0.33 & & 0.302 \\
2 & Tridacna crocea & 41 & & & 0.36 & 0.203 \\
\hline & & 45.5 & 0.0045 & 0.69 & 0.99 & 0.505 \\
\hline
\end{tabular}

Note: $X=$ Density; $H^{\prime}=$ Diversity Index; $E=$ Evennes Index; $D=$ Dominance Index.

Based on the above table, the diversity index produced is 0.69 ; this indicates a low level of diversity, as according to Shannon Wiener (Magurran, 2004) the diversity index in which $\mathrm{H}^{\prime}<1$ indicates a low level of diversity. This is understood as there were only two types of clams found in Negeri Morella, i.e. Tridacna squamosa L and Tridacna crocea. The biodiversity of waters is highly dependent on the number of species in the community, meaning that the more species found, and then the higher the diversity is (Wilhm and Doris, 1986). The low diversity index can be influenced by biotic and abiotic factors; biotic factors will influence directly or indirectly the presence, density, and distribution of species (McNaughton and Wolf, 1973). The abiotic factors affecting the distribution and diversity index of marine organisms, especially Tridacna, are temperature, substrate, and dissolved oxygen (Nybakken, 2001).

Based on observations, the evenness index $(\mathrm{E})$ obtained is 0.99 . Evenness expresses how evenly the individuals in a community are distributed among the different species (Odum, 1971). E value obtained belongs to the high category meaning that the population is highly even, or the number of individuals of each kind is the same. 
The dominance index (Krebs, 1989) shows a value of five (5), indicating a low dominance, i.e. the population is not dominated by other organisms.

\section{CONCLUSION}

There are two (2) types of giant clams found in Negeri Morella, i.e. Tridacna squamosa and Tridacna crocea, with population density of 45.5 individuals $/ \mathrm{Ha}$, diversity index $\left(\mathrm{H}^{\prime}\right)$ of 0.69 , evenness index (E) between 0-1, and dominance index (D) of 0.505.

\section{REFERENCES}

1. Braley, R.D. 1985. Serotonin-induced spawning in giant clams (Bivalvia: Tridacnidae). Aquaculture, 47 (4): 321-325.

2. Hamner, W.M. and M.S. Jones. 1976. Distribution, burrowing, and growth rates of the clam Tridacna crocea on interior reef flats. Oecologia, 24 (3): 207-227.

3. Hedley, C. 1921. A revision of the Australian Tridacna. Rec. Aust. Mus., 13, pp.163-172.

4. Hernawan, U.E. 2011. Taxonomy of Indonesian Giant Clams (Cardiidae, Tridacninae). Bonorowo Wetlands.

5. Kawaguti, S. 1983. Metamorphosis of the boring clam, Tridacna crocea. Proceedings of the Japan Academy, Series B, 59 (4): 67-70.

6. Krebs, C.J. 1989. Ecology Methodology. Harper and Row Publisher. New Yok: 224 pp

7. Magurran, A.E. 2004. Measuring biological diversity. Malden, Blackwell Pub. VIII+256 pp.

8. McNaughton, S.J. and Wolf, L.L. 1973. General Ecology. Holt, Rinehart \& Winston: New York.

9. Nontji, A. 2002. Laut Nusantara. penerbit Djambatan, Jakarta.

10. Nybakken, J.W. 2001. Marine biology: an ecological approach (Vol. 5). San Francisco: Benjamin Cummings.

11. Odum, E.P. 1971. Fundamental of Ecology. W.E. Sounders, Philadelphia: 574 pp.

12. Suzuki, Y. 1998. Preliminary studies of locomotion and burrowing by juvenile boring clam, Tridacna crocea. Naga, The ICLARM Quarterly, 21 (1):31-35.

13. Wells, S. 1997. Giant clams: Status, Trade and Mariculture, and the Roles of CITES Management. IUCN, Gland, Switzerland and Cambridge, UK.77 pp.

14. Wilhm, J. And L. Doris. 1986. Biological indicators of pollution, in B.A Whitton (Ed) River Ecologi Blackwell Scientifice Publication, Oxpord. London

15. Yonge, C.M. 1936. Mode of life, feeding, digestion, and symbiosis with zooxanthellae in the Tridacnidae (pp. 283-321). London: British Museum.

16. Yusuf, C., Ambariyanto, and R. Hartati. 2009. Abundance of Tridacna (Family Tridacnidae) at Seribu Islands and Manado Waters, Indonesia. Jurnal IImu Kelautan Universitas Diponegoro (UNDIP). Semarang, 14 (3):150-154. 